\title{
Relation of Emotional Intelligence, Self-esteem, Self-efficacy, and Psychological Well-Being Students of State Senior High School
}

\author{
Novi Rosita Rahmawati, Dany Moenindyah Handarini, Triyono \\ Course and Counseling-Universitas Negeri Malang \\ Jl. Semarang 5, Malang. E-mail: novi.rahmawati92@gmail.com
}

\begin{abstract}
This study aims to know the relation of emotional intelligence (X1) and psychological wellbeing (Y), the relation of self-esteem (X2) and psychological well-being (Y), as well as the relation of self-efficacy (X3) and psychological well-being (Y) of public senior high school in the entire Malang city. This study was a non-experimental study with causal relationship study plan. The result of this research showed that there was a positive significant correlation between $\mathrm{X} 1$ and $\mathrm{Y}, \mathrm{X} 2$ and $\mathrm{Y}, \mathrm{X} 3$ and $\mathrm{Y}$; $\mathrm{X} 1, \mathrm{X} 2, \mathrm{X} 3 \mathrm{had}$ strong linear relation with $\mathrm{Y}$; the influence of the three independent variables was $50.7 \%$, while the rest was influenced by other variables; $\mathrm{X} 2$ was the most influencing variable towards $\mathrm{Y}$, the second was X1, and the last was X3.
\end{abstract}

Key Words: emotional intelligence, self-esteem, self-efficacy, psychological well being, senior high school students

\begin{abstract}
Abstrak: Penelitian ini bertujuan untuk mengetahui hubungan kecerdasan emosi (X1) dan psychological well being $(\mathrm{Y})$, self esteem (X2) dan psychological well being (Y), self efficacy (X3) dan psychological well being (Y) siswa SMA Negeri se-kota Malang. Pendekatan yang digunakan adalah non experimental research dengan jenis penelitian causal relationship study. Hasil penelitian menunjukkan ada hubungan positif signifikan antara X1 dan Y, X2 dan Y, X3 dan Y; X1, X2, X3 memiliki hubungan linear yang kuat dengan Y; pengaruh ketiga variabel independen sebesar 50,7\%, sedangkan sisanya dipengaruhi oleh variabel lain; X2 vaktor yang berpengaruh terhadap Y, urutan kedua X1, dan urutan terakhir adalah X3.
\end{abstract}

Kata kunci: kecerdasan emosi, self esteem, self efficacy, psychological well being, siswa SMA

Ryff(1989) defined someone with psychological wellbeing (PWB) as an individual who has positive attitude toward his/her own self and other people, able to make decision, able to create and manage environment which is suitable to the needs, has purpose of life and make meaningful life, also, struggle to explore and develop his/her own self. In order to depict PWB Rosenberg (1965) used self-concept and self-esteem. While Diener, et al (1985) used mood, affect, quality of life mentality, and subjective well-being. Some definitions which have been mentioned shows that PWB is important to support the individual's success.

One of the factors that influence PWB is emotional intelligence. Goleman (1995) stated that each individual who is emotionally smart will experience higher psychology welfare than individual who has low emotional intelligence. It is caused by individual who has emotional intelligence able to keep the positive mental and decrease or fade negative emotions because their ability in managing (admit, understand, produce, and manage) his/her own emotions effectively.

There is not only emotional intelligence which should be developed, another factor that influence PWB is self-esteem. Santrock (2008, p. 127) stated that there are two important aspects from individual, they are self-esteem and identity. The result of the research of Schilling $(2015$, p. 3) showed that individual with high self-esteem has higher score in all sub-scale welfare. In line to the result of the research, Susanti (2012) also showed that there was positive relation between self-esteem and PWB. It means that higher self-esteem will result to higher PWB too.

The next factor which is assumed as important factor to increase PWB is self-efficacy. Caroli and 
Sagone (2014, p. 867) stated that there is positive relation of self-efficacy and PWB especially controlling, individual growth, and self-acceptance. The more productive individual will result to higher score of $\mathrm{PWB}$ especially in controlling, individual growth, and selfacceptance.

SMA students in general are in the teenage age. Routledge (2007) give explanation those teenagers who have higher welfare, able to fulfill the demand of situation and success in facing the burden of life. While in opposite, teenager with low welfare sometimes they are not really success to fulfill the demand of life and almost got social distraction or emotional distraction.

Based on the result in the field showed that 20 student's grade X MIAC SMAN 3 Malang who didn't take the decision by their own self about choices of interest and career. Those two choices are taken based on the desire and interest of the parents with no consideration of children's hope. This moment showed that they didn't have autonomy and purpose of life. Autonomy and purpose of life are two aspects in PWB. If students do not have autonomy and purpose of life, the students will always depend to another people. Meaning that the students with low PWB caused by two of six aspects in PWB are not comprehended.

School as formal institution has strategic role in minimizing the raising of problem intensively and continuously in order to impose and develop individual right, values, moral, and self-belonging; therefore, since teenager, they can develop a happy life and welfare. Program of BK is existed at school to give the right and appropriate in increasing PWB, understand factors that influence PWB are wise actions for counselor. When counselor is Able to know factors that influence PWB the effort to increase PWB become eaier.

Based on the condition which can be formulate that problems (1) relation of emotion and PWB of students SMAN in Malang city, (2) relation of selfesteem and PWB of SMAN in Malang city, (3) relation of self-efficacy and PWB of students at SMAN in Malang city, (4) relation of emotion intelligence, self-esteem, and self-efficacy toward PWB, (6) The contribution effectives of each various emotional intelligence, self-esteem, self-efficacy toward PWB of SMAN students at Malang City.

\section{METHOD}

The methodology is non-experimental research with causal relationship study. The design of relationship study is used because this research will not be manipulated, comparing and treatment toward variables. There are three independent variables and one dependent variable. Independent Variables are emotional intelligence, self-esteem, and self-efficacy, while dependent variable is PWB.

Population of research is all students in grade $\mathrm{X}$ and XI SMAN in Malang City at 2015/2016. Population is taken from grade X and XI because in first semester XII graders are not allowed to be the sample. The technique to take sample is cluster random sampling.

First step is deciding number of the subjects who will be the sample by using formula from Slovin. From the number of population 6068 students with minimum accuracy 0,05 , the researcher can get 379.25 or 379 students. Second step is choosing randomly from the ten schools SMAN in Malang city which is located in three sub-district (sub district Klojen, Lowokwaru, and Kedungkandang). SMAN 2 Malang and SMAN 3 Malang represent sub district Klojen, SMAN 7 Malang represents Sub district Lowokwaru, and SMAN 10 Malang represents sub district Kedungkandang. The last step is deciding the class that will be the respondent with random and based on the suggestions of the counselor.

Instruments of emotional intelligence, self-esteem, self-efficacy and PWB are used to collect data. Instruments are made based on the main items that have been settled with adopted from the experts. Instruments of emotional intelligence is adopted from the London Leadership Academy, self-esteem is adopted from the Inventory (SEI) Coppersmith (1967). (In Mangantes, 2005), self-efficacy is adopted from MorganJinks Students Efficacy Scale (MJESES), and PWB is adopted from Psychological Well-Being Scales from Ryff. Trial process of instruments is done before conducting the research. The purpose of the trial process is to know level of validity and reliability of instruments. Trial process is given to the students of X SCIENCE 6, XI Language, XI SCIENCE 6, X IPS 1, XI SCIENCE 3, and XI SCIENCE 5 SMAN 5 Malang.

Technique of data analysis is regression double linier. Analysis regression double linier is used to answer the research problem such as (1) finding the relation of emotional intelligence and psychological well-being; (2) deciding the relation of self-esteem and psychological well-being; (3) deciding the relation of self-efficacy and psychological well-being; (4) finding the relation of emotional intelligence, self-esteem, self-efficacy, and psychological well-being; (5) contribution of relative independent variables together with independent variables;(6) contribution effectives in each of independent 
variables one by one toward dependent variable. Before the test of regression double linier is done, the researcher will conduct test of assumption pre-requirements (Santoso in Atmoko, 2012, p. 124). Test of assumption consists of normality test, heteroscedasticity test, and multicolinearity test.

\section{RESULTS}

\section{Assumption Test}

The result of normality test showed that significant score of Emotional variable (X1) is 0.133 . Significant score of self-esteem variable (X2) is 0.421 . Significant score of self-efficacy variable (X3) is 0.115 , it can be concluded that all datum in four variables is normal distribution based on the heteroscedasticities test found that the data distribution in the chart mostly make a formation but still can be assumed doesn't show heteroscedasticities. It is shown that the points are spread above and under 0 score $Y$ line. Then, conducting multicollinearity test as the settle requirements of analysis double regression model. The result of multicollinearity test is tolerance score for $\mathrm{X} 1$ is 0.817 . Tolerance score for $\mathrm{X} 2$ is 0.864 , tolerance score for $\mathrm{X} 3$ is 0.787 . This means that score tolerance of three variables is bigger than 0.10 . While VIF for $\mathrm{X} 1$ is $1.224, \mathrm{X} 2$ is $1.157, \mathrm{X} 3$ is 1.270. Meaning that VIF score of three variables is less than 10.00 and it can be concluded that multicollinearity doesn't happen among three independent variables.

\section{Relation Of Emotional Inteligencence And Psychological Well-Being}

The result of regression analysis is shown that $\mathrm{t}$ count $=|4.117|(>$ table 1,966), score Sig $=0,000(<$ $0,05)$, meaning H0 is refused and $\mathrm{Ha}$ is accepted. Based on the result it can be concluded that emotional intelligence $(\mathrm{X} 1)$ has significant relation with $\mathrm{Y}(\mathrm{Y})$ toward SMAN in Malang city.

\section{Relation Of Self-Esteem And Psychological Well-Being}

The result of analysis showed that $\mathrm{t}$-count $=$ $|15.499|\left(>t_{\text {able }} 1,966\right)$, score Sig $=0,000(<0,05)$. Meaning that $\mathrm{H} 0$ is refused and $\mathrm{Ha}$ is accepted. Based on the result it can be concluded that self-esteem (X2) has significant relation with psychological well-being $(\mathrm{Y})$ in students of SMAN all over Malang.

\section{Relation Of Self-Efficacy And Psychological Well-Being}

The result of analysis showed that $\mathrm{t}_{\text {count }}=|2.867|$ $\left(>t_{\text {able }}, 1,966\right)$, score $\operatorname{Sig}=0,004(<0,05)$. Meaning that $\mathrm{HO}$ is refused and $\mathrm{Ha}$ is accepted. According to the result it can be concluded that self-efficacy (X3) has significant relation to the psychological well-being among the students of the SMAN in Malang city.

\section{Relation Of Emotional Intelligence, Self- Esteem, Self-Efficacy And Psychological Well- Being}

$\mathrm{R}$ score showed the strength of linier relation and direction of the four variables (Emotional Intelligence, self-esteem, self-efficacy And Psychological WellBeing). R (coefisien correlation) is positive at 0.71 . Independent Variables (Emotional Intelligence, selfesteem, and self-efficacy) and dependent variable (Psychological Well-Being) can be categorized as strong linier relation. Meaning that if Emotional Intelligence, self-esteem, self-efficacy are high, the score of psychological well-being is also high.

\section{Effective Contribution Together Of All Variant Emotional Intelligence, Self-Esteem, Self- Efficacy and Psychological Well Being}

It is known that the score $\mathrm{F}_{\text {count }}$ is $133,064 . \mathrm{F}_{\text {count }}$ $\geq \alpha$, which $\alpha$ is 0,05 . So, $133,064 \geq 0,05$ and can be concluded that $\mathrm{H}_{0}$ is refused. It is noted that emotional intelligence, Self-esteem, and Self-efficacy have significant influence in stimulating with Psychological Well Being.

Adjusted R square score is 0.507 . This means that $50.7 \%$ variations of psychological well-being can be explained by three free variables. While the rest $(100 \%-50.7 \%=49.3 \%)$ can be explained by other causes. Standard Error of Estimate (SEE) is 5.634. Meaning that the fault percentage to predict psychological well-being of SMAN students in Malang is around 5. Getting smaller the SEE will result to smaller fault of prediction, meaning that regression model is accurate to predict dependent variables. 


\section{Effective Contribution Of Each Variant \\ Emotional Intelligence, Self-esteem, Self- Efficacy And Psychological Well Being}

Based on the double regression test, influences of emotional intelligence toward psychological wellbeing is $16.3 \%$. Self-esteem influences the psychological well-being in $59.6 \%$. While self-efficacy influences psychological well-being in $11.6 \%$. It can be concluded that from three free variables which influence in big amount toward psychological well-being is self-esteem variable.

\section{DISCUSSION}

\section{Relation of Emotional Intelligence And Psychological Well-Being of SMAN Students In All Over Malang City}

The result of analysis is show that there is significant relation between emotional intelligence toward PWB of SMAN students in Malang City. The score that can be counted is 4.117 ; where tcount $>t_{\text {table }} 1.966$ with significant 0.000 or less than 0.05 . It means that higher emotional intelligence owned by the students will be followed by high score of PWB. In opposite, low emotional intelligence will be followed by low score of PWB. This finding is in line with the Salovey and Mayer research in 1990. According to Salovey and Meyer (in Carmeli, dkk, 2009, p. 68), each individual who has emotional intelligence tends to have higher PWB.

While from another research of Salovey and Meyer, the research of Cameli (2003) mentioned that there is positive relation between emotional intelligence and PWB. It is caused by each individual with high emotional intelligence will be better and careful while solving the conflict compared to individual with low emotional intelligence. Individual who has emotional intelligence thinks rationally and makes decisions with right method and time.

Hutapea (2011, p. 71) stated that individual who wants PWB will stay in the level or good score. Therefore, they need higher emotional intelligence to support it. Agreed to Hutapea (2011), Gohm and Clore (2012) stated that individual who has emotional intelligence can control their emotion related to PWB positively.

PWB is almost related to the health of mentality. Meyer and Savey (in Carmeli,dkk, 2009, p. 69) stated that individual who owned emotional intelligence will be able to keep positive mentality caused by their ability to control their emotion actively by recognizing, understanding, generating, regulating, and promoting. It can be concluded when individual has high emotional intelligence, they will have high PWB. Person with emotional intelligence can detect their own emotion, control of emotion, self-motivation, self-acceptance, has positive relation to other people, independent, environment authority, have purpose of life, and can pass the growing phase well.

\section{Relation Of Self-Esteem And Psychological Well-Being Of SMAN Students In All Over Malang}

The result shows that significancy is 0.0000 which means that lesser than 0.05 . Based on the results it can be concluded that self-esteem has positive relation with PWB of SMAN students in allover Malang. It is also agreed by Nwankwo, Okechi, \& Nweke (2015), Schilling (2015), Rigby (2003), McNeely,et al. (2002), Sarkova (2013). Susanti (2012) that mentioned higher self-esteem will result in higher PWB too.

Campbel (in Mehmood dan Gulzar, 2014, p. 178) stated that self-esteem, self-actualization, stress, anxiety, and depression are key components from PWB. PWB is argued as significant to face the challenge of life. It can be stated that the students who are accepted is given attention and care from other people. They are able to control their acts, support their own self, and independent. They are also able to obey the moral ethic code and religious principles will give positive influence toward their PWB.

Research from Yumus, et al. and Sarkova support Rigby's finding (2003); Mc Neely, et al. (2002) which showed that the students who are satisfied toward their relation at school have higher PWB. They will have better relation, better PWB, higher positive selfesteem, and lower self-esteem. Schilling (2015, p. 3) showed that students with high self-esteem assumed to have higher welfare in all sub-scale of welfare. The findings of this research have important implication to understand that self-esteem influences PWB.

Therefore, it can be concluded that when individual has high self-esteem, they will also have high PWB. Individual with high self-esteem can be detected by owning some aspects such as meaningful, strength, ability, and goodness. Those four aspects can make individual accept their own self, have positive relation with others, independent, environtment authonomy, have purpose of life, and pass the growing phase well. 


\section{Relation Of Self-Efficacy And Psychological Well-Being of SMAN Students In All Over Malang}

The result of the research showed that there is significant relation between self-efficacy and PWB. This is proven that result of analysis t-count bigger than t-table and the score of significancy is less than 0.05 . T-count has score 2.867 while t-table 1.966 and score of significance is 0.004 . The result supports previous findings that stated self-efficacy has significant relation with PWB.

This result is in line with Siddiqui. Siddiqui (2015) stated that PWB and self-efficacy can predict the works and success of the students in the courses. This research also mentions that students who have high self-efficacy and PWB can be motivated to participate in relevant academic activities and built positive acts which can resulted in successful school phase. The previous research from Soysa dan Wilcomb (2013), Salami (2010), and Natovová (2014) also support that self-efficacy has influence toward PWB.

According to Bandura (in Siddiqui: 2015, p. 6) high self-efficacy is related to positive well-being, regulation of stress, higher self-esteem, better physical condition, and better adoption. In other side, individual who has low self-efficacy mostly got worried feelings and depression. Students with self-efficacy they will be able to enjoy their life. When in stress condition, the students will be conscious with their ability to control situation which can be beneficial for them and give them confidence.

The result of Salami (2010, p. 251) explained that students' attitude and acts can be predicted from independent variables, emotional intelligence, and selfefficacy. Students with high self-efficacy, high emotional intelligence, and happiness can be motivated to give participation in relevant academic activities and develop positives acts toward success in higher education.

Students with good self-efficacy can be known from the way they do the hard tasks, do the task alone, and do not give up. Those three aspects can make individual to accept their own self, have positive relationship with other people, independent, has purpose of life, and develop positives attitude by passing growing phases well.

\section{Implication Toward Course And Counseling}

Pajares dan Schunk (2001) stated that students with high PWB and life satisfaction will be more flexible, brave, and efficient in solving problem. Students also have more commitment toward their academic purposes and focus to be successful. In the arguments with Pajares dan Schunk, Caroli and Sagone (2014) stated that the more productive students, the score PWB will be higher too especially in comprehending, self-development, and self-acceptance. It means that te students are expected to have high PWB score in order to be able in taking decision and responsible with their life.

According to Salami (2010, p. 251) the students who have high self-efficacy, emotional intelligence, and PWB can be motivated to participate in every academic activities. Also, their positive attitude can be developed to higher education. Caroli \& Sagone $(2014$, p. 867) stated that there is positive relation of self-efficacy and PWB. Therefore, the more active students, their score of comprehending, self-development, and selfacceptance will be higher.

According to Natovová (2014, p. 17) self-efficacy can be the concept in education and counseling which relate to stress management. It is showed that counselor can help students to increase emotional intelligence, self-esteem, self-efficacy, and PWB in order to strengthen self-potential of teenagers. Therefore, students can do the growth tasks well.

Students with low PWB score will result to low emotional intelligence, self-esteem, and self-efficacy. To get good score of PWB, they need counselor to help them understanding the importance of comprehending PWB. It is stated in the decree of ministry education and culture (Permendikbud) No. 111 year 2014 about the course and counseling in primary school and tertiary school that the existence of Course and Counseling at school in order to facilitate students to achieve independence in the form of understanding, accepting, directing, taking decision, and actualizing by being responsible to achieve happiness and welfare in life.

\section{CONCLUSION}

According to the result of hypothesis testing it can be concluded that there is relation of each independent variable (emotional intelligence, self-esteem, and self-efficacy) with dependent variable (PWB). Emotional intelligence significantly gives positive influence toward PWB. Self-esteem intelligence significantly gives positive influence toward PWB. Self-efficacy intelligence significantly gives positive influence toward PWB. 
Emotional intelligence, self-esteem, and self-efficacy have strong linier relation. Those three independent variables (emotional intelligence, self-esteem, and self-efficacy) have significant influence in the form of stimulation toward PWB. Self-esteem is the most influ-ential toward PWB, the second place is emotional intel-ligence, and the last is self-efficacy.

There is still other factors that influence the high and low score of PWB, therefore, suggested to other researchers next time to reveal those factors in the level of primary education until tertiary education. If it is found various factors can influence PWB of the students. It will be the new perspectives of course and counseling research.

The purpose of increasing students' $\mathrm{PWB}$, is that counselor can increase emotional intelligence with Counseling Rationale Emotive Behavior Therapy (REBT) service with narrative approach (Tyas, 2013). While to increase self-esteem counselor can use reality counseling with metaphor techniques (Rahman, 2013). Besides using reality counseling with metaphor techniques to increase self-esteem, counselor can use role play technique (Nuraini, 2012).

In the moment of increasing PWB, counselor can increase self-efficacy through group counseling with metaphor technique in the form of healing stories (Wahid, 2012). Also, counselor can use Rainbow Wheels (Setyaputri, 2014).

Those efforts that have been given by the previous researcher can be implemented by the counselor to increase students' PWB. If counselor can increase Psychological well-being, we can say that counselor has helped students to achieve growth tasks.

\section{REFERENCES}

Agustiani, H. (2006). Psikologi perkembangan: pendekatan ekologi kaitannya dengan konsep diri dan penyesuaian diri pada remaja. Bandung: PT Refika Aditama.

Ali, M., Asrori, M. (2012). Psikologi remaja: perkembangan peserta didik. Jakarta: Bumi Aksara.

Atmoko, A. (2012). Bahan ajar matakuliah desain dan analisis data. Universitas Negeri Malang, Malang.

Carmeli, A. (2003). The relationship between emotional intelligence and work attitudes, behavior and outcomes. Journal of Managerial Psychology, 18(8), 788-813. https://doi.org/10.1108/02683940310511881

Carmeli, A., Yitzhak-Halevy, M., \& Weisberg, J. (2009). The relationship between emotional intelligence and psychological wellbeing. Journal of Managerial Psychology, 24(1), 66-78. https://doi.org/10.1108/ 02683940910922546.

Caroli, M.E. De, \& Sagone, E. (2014). Generalized self-efficacy and well-being in adolescents with high vs. low scholastic self-efficacy. Procedia-Social and Behavioral Sciences, 141, 867-874. https://doi.org/ 10.1016/j.sbspro.2014.05.152.

Coopersmith, S. (1967). The antecedents of self-esteem. San Francisco: Freeman.

Diener, E., Emmons, R. A., Larsen, R. J., \& Griffin, S. (1985). The satisfaction with life scale. Journal of Personality Assessment, 49(1), 71-75.https://doi.org/10.1207/ s15327752jpa4901_13.

Gohm, C. L., \& Clore, G. L. (2002). Four latent traits of emotional experience and their involvement in wellbeing, coping, and attributional style. Cognition \& Emotion, 16(4), 495-518. https://doi.org/10.1080/ 02699930143000374.

Goleman, D. (1995). Kecerdasan emosional. Terjemahan T. Hermaya. 2003. Jakarta: Gramedia Pustaka Utama.

Hooper, J. (2012). What children need to be happy, confident and successful: step by step children flour$i s h$. London and Philadelphia: Jessica Kingsley Publishers.

Hurlock, E. B. (1978). Perkembangan anak. Jakarta: Erlangga. Hutapea, B. (2011). Emotional intelegence dan psychological well-being pada manusia lanjut usia anggota organisasi berbasis keagamaan di jakarta. INSAN, $13(2): 64-73$.

Lestari, L.P.S. (2013). Keefektifan pelatihan metode self instruction dalam meningkatkan self-esteem siswa $S M A$. (Unpublished master's thesis). Universitas Negeri Malang, Malang.

Mangantes, M.L. (2005). Hubungan antara pola asuh orang tua, kelas sosial, kemampuan umum dan self-esteem siswa SMA negeri di kota Malang. (Unpublished master's thesis). Universitas Negeri Malang, Malang.

Mehmood, T., \& Gulzar, S. (2014). Relationship between emotional intelligence and psychological wellbeing among Pakistani adolescents. Asian Journal of Social Science \& Humanities, 3 (3): 178-185.

Natovová, L., \& Chýlová, H. (2014). Is there a relationship between self-efficacy, well-being and behavioral markers in managing stress at university students. Journal on Efficiency and Responsibility in Education and Science, 7(1), 14-18.

Nuraini. (2013). Efektivitas teknik role-play untuk meningkatkan self-esteem peserta didik (studi eksperimen kuasi terhadap peserta didik kelas $x$ negeri 
15 Jakarta tahun ajaran 2012/2013). (Unpublished master's thesis). Universitas Pendidikan Indonesia, Bandung.

Nwankwo, C. B., Okechi, B. C., \& Nweke. P.O. (2015). Relationship between perceived self-esteem and psychological well-being among student athletes. Academic Research Journal of Psychology and Counseling, 2(1): 8-16.

Pajares, F., \& Schunk, D. H. (2001). Self-beliefs and school success: self-efficacy, self-concept, and school achievement. Perception, 11, 239-266.

Menteri Pendidikan dan Kebudayaan Republik Indonesia. (2015). Peraturan menteri pendidikan dan kebudayaan republik indonesia nomor 111 tahun 2014 tentang bimbingan dan konseling pada pendidikan dasar dan pendidikan menengah.

Rahman, D. H. (2013). Keefektifan teknik metafora dalam bingkai konseling realitas untuk meningkatkan harga diri siswa SMA. (Unpublished master's thesis). Universitas Negeri Malang, Malang.

Rosenberg, M. (1965). Society and the adolescent selfimage (Vol. 11, p. 326). Princeton, NJ: Princeton University Press.

Routledge, L. (2007). Well-being of south african adolescents in an urban context. (Unpublished master's thesis). University of Pretoria, Hatfield

Ryff, C. D. (1989). Happiness is everything, or is it? Explorations on the meaning of psychological well-being. Journal of Personality and Social Psychology, 57(6), 1069-1081.

Ryff, C. D., \& Singer, B. (1996). Psychological weil-being: meaning, measurement, and implications for psychotherapy research. Psychotherapy and Psychosomatics, 65(1), 14-23. https://doi.org/10. 1159/000289026.

Sagone, E., \& Caroli, M. E. De. (2014). Relationships between psychological well-being and resilience in middle and late adolescents. Procedia-Social and Behavioral Sciences, 141, 881-887. https://doi.org/ 10.1016/j.sbspro.2014.05.154.

Salami, S. O. (2010). Emotional intelligence, self-efficacy, psychological well-being and students attitudes: implications for quality education. European Journal of Educational Studies, 2(3), 247-257.

Salami, S. O. (2011). Personality and psychological wellbeing of adolescents: the moderating role of emo- tional intelligence. Social Behavior and Personality: an international journal, 39(6), 785-794. https:/ /doi.org/10.2224/sbp.2011.39.6.785.

Santrock, J.W. (2008). Psikologi pendidikan. Jakarta: Salemba Humanika.

Schilling, K. (2015). Examining the role of self-esteem in the association between emotional vulnerability and psychological wellbeing. (Unpublished master's thesis). University of Daxton.

Setyaputri, N. Y. (2014). Pengembangan media permainan "roda pelangi" untuk meningkatkan efikasi diri siswa SMP dalam menghadapi ujian. (Unpublished master's thesis). Universitas Negeri Malang, Malang.

Siddiqui, S. (2015). Impact of self-efficacy on psychological well-being among undergraduate students. The International Journal of Indian Psychology, 2(3), 5-16.

Susanti, S. (2012). Hubungan harga diri dan psychological well-being pada wanita lajang ditinjau dari bidang pekerjaan. Calyptra, 1(1), 1-8. Retrieved from http:/ /www.journal.ubaya.ac.id/index.php/jimus/article/ view/70.

Tyas, P. H. P. (2013). Efektivitas konseling rational-emotif behavior therapy (REBT) dengan pendekatan naratif untuk meningkatkan kecerdasan emosional. (Unpublished master's thesis). Sekolah Pascasarjana Universitas Pendidikan Indonesia, Bandung.

Wahid, H. (2012). Keefektifan konseling kelompok dengan teknik metafora berbentuk healing stories untuk meningkatkan efikasi diri akademik siswa SMA pada mata pelajaran matematika. (Unpublished master's thesis). Universitas Negeri Malang, Malang.

Yi, C.-C., Wu, C.-I., Chang, Y.-H., \& Chang, M.-Y. (2009). The psychological well-being of taiwanese youth. International Sociology, 24(3), 397-429. https:// doi.org/10.1177/0268580909102914.

Yunus, F. W., Mustafa, S. M. S., Nordin, N., \& Malik, M. (2015). Comparative study of part-time and full-time students' emotional intelligence, psychological well-being and life satisfactions in the era of new technology. Procedia - Social and Behavioral Sciences, 170, 234-242. https://doi.org/10.1016/ j.sbspro.2015.01.033. 